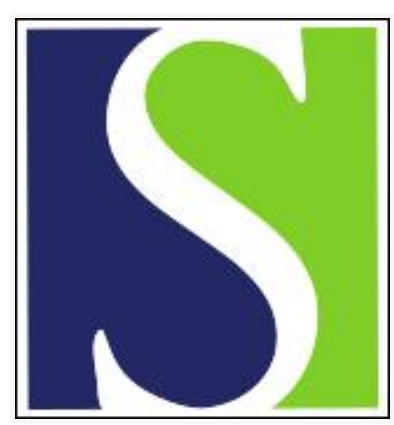

Scand J Work Environ Health 1986;12(5):439-447

https://doi.org/10.5271/sjweh.2114

Issue date: Oct 1986

Clinical aspects of the hand-arm vibration syndrome. A review. by Pyykko I

This article in PubMed: www.ncbi.nlm.nih.gov/pubmed/3538376

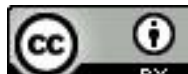




\title{
Clinical aspects of the hand-arm vibration syndrome
}

\section{A review}

by IImari Pyykkö, MD ${ }^{1}$

\begin{abstract}
PYYKKÖ I. Clinical aspects of the hand-arm vibration syndrome: A review. Scand $J$ Work Environ Health 12 (1986) 439-447. At present it seems likely that the different components of the hand-arm vibration syndrome, eg, vibration-induced white finger (VWF), numbing of the hands and arms, muscular fatigue, and occasionally prevalent bone degeneration, may arise independently, and therefore they should be evaluated separately. Evidence of changes caused in the autonomic nervous functions of the body by local vibration is not conclusive. The vascular history should be confirmed objectively with a cold provocation test under laboratory conditions. In individual diagnostics it is useful to record (with modern plethysmographic techniques) the recovery of digital temperature, digital blood pressure, and flow after local cooling. Vibrotactile perception measurement seems to be suitable for group diagnosis. Much of the diagnostic weight for VWF can be obtained from accurate case histories, although, for early changes, the history may be atypical. The lack of simple objective tests for evaluating the hand-arm vibration syndrome makes it difficult to, eg, confirm the history of its different components objectively and estimate the extent of the disability it causes.
\end{abstract}

Key terms: local vibration, muscle fatigue, paresthesias of the hands and arms, vibration-induced white finger.

Several surveys have confirmed the connection between the vibration of hand-held tools and disturbances in the circulation of the fingers $(4,6,20,36,37)$. As knowledge has advanced, it has become evident that vibration may also cause symptoms in the peripheral nerves and muscles and in some cases even in the bones and joints (110). The whole collection of symptoms is known as the "hand-arm vibration syndrome" ( $(91$, $110)$. The different symptoms of the hand-arm vibration syndrome may occur together or separately $(89$, 95,110 ). They may also arise independently of each other and therefore could have, at least to some degree, different etiologic mechanisms.

The vascular symptoms of the hand-arm vibration syndrome resemble the spontaneous vasoconstrictive disease first described by Raynaud $(60,101)$, in which paroxysmal ischemia in digits or hands is provoked by cold weather. The constriction of finger vessels usually lasts from 5 to $30 \mathrm{~min}$, during which the fingers look white and pale $(18,89)$. Recovery is achieved spontaneously or by the massaging or local warming of the hands. These vasoconstrictions seldom lead to malnutrition or atrophy of the skin, although such cases have been reported $(15,110,115)$. The vascular disorders of the vibration syndrome are also called a wide variety of names, eg, Raynaud's phenomenon of occupational origin (5), white fingers, dead fingers (36, 37), traumatic vasospastic disease (TVD) (33), and

\footnotetext{
1 Institute of Occupational Health, Helsinki, Finland.
}

Reprint requests to: Dr I Pyykkö, Department of Physiology, Institute of Occupational Health, Laajaniityntie 1, SF-01620 Vantaa, Finland. lately - according to the British Industrial Advisory Council - "vibration-induced white finger" (VWF) (108).

Workers using vibrating tools commonly experience numbing and lacerating pain in the arms and hands $(55,105)$. Such symptoms are distressing because they wake the worker at night and force him to massage his hands, his sleep rhythm thus being disturbed. These symptoms have been linked to neuropathy caused in peripheral nerves by vibration. However, a few researchers have pointed out the possibility that some of the symptoms might be due to entrapment of the nerve trunk in the cervical, ulnar, or carpal areas (7, $63,66)$. The prevalence of paresthesias ranges from 30 to $80 \%$ among different groups of workers $(2,8$, $56,73,105)$. It has been suggested that advanced muscle atrophies arise secondarily to nerve damage $(63,110)$.

Data on the prevalence of extensive muscle fatigue in the hands and arms of forest workers, 14 to $35 \%$ of whom has experienced such fatigue, indicate that exposure to occupational vibration may lead to inadequate muscle contraction $(56,73,98)$. Färkkilä $(25)$ and Färkkilä et al $(26,27)$ have consistently demonstrated that acute and chronic exposure to vibration leads to a significant decrease in the muscle force of the hands. Since Banister \& Smith (13) showed that the use of vibrating tools is associated with a significant decrease in manipulative dexterity, it seems possible that muscular weakness is at least partly due to a disturbance of the fine control of the muscles of the hands. A correlation has also been found between the decrease in muscle force and nerve conduction veloc- 
ity (Pyykkö et al, unpublished observation). The nerve degeneration which innervates the muscles might be the immediate cause of excess muscle fatigue, although a direct effect of vibration on the contractive proteins in the muscle cannot be ruled out.

Skeletal changes in the wrist, ie, vacuoles, cysts and decalcification, is not so common in vibration-exposed workers as vascular or nervous disorders. Laitinen et al (59) observed bone cysts and vacuoles in $26 \%$ of a sample of professional lumberjacks using chain saws and thus confirmed the findings of Kumlin et al (57) and of Horwath \& Kakosy (41). However, Vainio (113) reported a considerably higher prevalence of these changes among workers using rock drills. In contrast to these studies, which lacked reference groups, Hellström \& Lange Andersen (38), James et al (47), and Härkönen et al (34) were unable to show any significant increase in the number of degenerative bone changes in the wrist among subjects exposed to chainsaw vibration in comparisons with referents. Thus conclusive evidence of changes as a result of vibration in certain occupations, eg, forest work, is still lacking.

Osteoarthrotic disturbances in the elbow are not believed nowadays to constitute an important component of the hand-arm vibration syndrome or even exist as the result of vibration exposure alone. It is clear from reviewing available literature that osteoarthrosis, as well as other bone and joint changes, is so rare among the working aged population that this fact alone almost precludes an essential harmful influence from the very widespread use of vibrating tools. Under certain circumstances [namely, as a combined effect of strong and long-lasting static and dynamic load on a joint held in a physiologically unsuitable position during work with a tool producing very low-frequency vibration of shock type, eg, during rock drilling (113)] arthrosis of the elbow joint may develop (prematurely) in some individuals, especially in those with a constitutional weakness of the musculoskeletal apparatus.

Workers using vibrating tools may experience pain in the wrist and elbow joints $(18,55,106)$. Experience has shown, moreover, that a person who has received an injury to the bones of the arms or hands is often not able to work with vibrating instruments because of resulting pain in the previously injured tissue (90). No conclusive evidence has yet been accumulated, however, for the occurrence of arthrosis of joints as a result of vibration, though some of the data suggest that it is possible (86).

\section{A central or a peripheral disorder?}

Although vibration syndrome is characterized by vascular and peripheral nervous symptoms, several reports, especially from the Soviet Union and Japan, indicate a possibility that the central nervous system (CNS) may be involved in the vibration syndrome (9, $11,68,73,78)$. The cardiovascular responses tend to become overactive after prolonged exposure to vibration $(43,68,95)$. Involvement of sensory function outside the hands and arms has also been indicated by data showing that auditory functions are more deteriorated in subjects with than in those without VWF even though the exposure to vibration was the same $(44,45$, 99,100 ).

Consequently, some of the literature treats vibration syndrome as a disorder entity which is thought to originate from continuous reflex activation of the hypothalamic autonomic centers, causing a maladaptation response $(30,31,67,70)$. The disorder is said to comprise several stages which, when combined, correspond to the classification system of AndreevaGalanina $(30,31)$.

In patients not exposed to vibration, the true autonomic dysfunction ("autonomic neuropathy") is, in general, linked to certain degenerative disorders (to Parkinsonism in about $75 \%$ of some series) or to cerebellar-brainstem disorders $(14,103,111)$. Symptoms and signs may be numerous $(39,42)$. In true autonomic neuropathy orthostatic hypotension is the leading symptom, characterized by attacks of syncope and dizziness. Asthenia and impotence can also be frequently observed among the subjects, as well as anhidrosis, incontinence, and constipation.

Symptoms similar to those found in autonomic dysfunction have been observed among forestry workers. (See references, eg, 24, 69, 70, 71, 72, 116.) According to field studies, these symptoms occur more frequently among subjects with than among those without VWF (116).

Special emphasis has been focused on sleep disturbances in association with vibration syndrome. Thus Futatsuka et al (24) reported insomnia for as many as $90 \%$ of their severely affected subjects. Watanabe (116) reported difficulties of falling asleep for $22 \%$ of the workers examined, and spontaneous awakening during the night for an additional $18 \%$. However, insomnia, as are many of the proposed "autonomic symptoms," is a frequent complaint in modern society, where about 30-40\% suffer from transient insomnia and about $10-15 \%$ from permanent sleep disturbances (118). Furthermore, as indicated by Matoba and co-workers $(67,70)$, the causative factor is not evident from the prevalence data, since temporary conflicts in daily life (118) may interfere with the quality of life perceived. A more comprehensive analysis of the various factors involved is called for in the case of vibration-exposed workers.

The most comprehensive study of the role of the sympathetic nervous system has been carried out by Matoba and his co-workers $(67,68,69,70,71)$. They have developed an autonomic nervous system test, in which noise at $102-105 \mathrm{~dB}(\mathrm{~A})$ is presented through headphones. The circulatory responses are monitored with plethysmography, and the recovery of the pulse volume is observed. The results were interpreted as support for the idea that vibration from hand-held tools 
may increase the tone of the vasoconstrictor and pseudomotor systems, and this increase, after prolonged exposure, may lead to paralysis of the autonomic functions (72). Similar observations have been made by other researchers using digital plethysmography $(88$, 93). According to my own experience, these results are not conclusive for autonomic dysfunction, since peripheral vascular changes (eg, in persons with hypertrophy of the medial layer of the vessel wall and increased smooth muscle sensitivity to catecholamines) may strongly modify the responses $(92,94)$. Matoba et al (72) found a remarkably poor correlation between plethysmographic findings and the results of the cold provocation test.

In summary, there are hitherto no conclusive data that vibration induces chronic disturbances in the central autonomic nervous system. The central disturbances may result from dysfunction associated with the working situation itself and may not necessarily be directly related to exposure to vibration. Therefore the possible central disturbances linked to work with vibrating tools should not yet be included in the disease entity of the vibration syndrome.

The fact that localization of vibration-induced symptoms depends on contact with a vibrating tool (61) and, hence, may be asymmetrical (29) favors the opinion that vibration syndrome in the hands is a local disorder. Furthermore, workers who press vibrating tools with the legs may develop Raynaud's phenomenon in their legs (74). The symptoms can be also provoked by local cooling (80) when the rest of the body is heated (10). In contrast they are extremely difficult to provoke with central cooling if the affected finger is kept warm (10). Thus clinical data favor a localized lesion. In several countries vibration syndrome is considered to be an entirely peripheral disorder.

\section{Disability caused by vibration-induced white finger}

The vascular symptoms of the vibration syndrome seldom cause occupational disability in industrial workers who operate at room temperature. In spite of the annoyance during leisure-time activities in cold weather there is no loss of worktime or efficiency $(5,12)$. In outdoor workers, like lumberjacks, occupational disability must be expected but is often difficult to assess because it is transient and depends upon external factors like season, climate, mode of transportation, or clothing $(5,18,89,95,102)$.

The annoyance caused by VWF has been investigated with questionnaire studies. Grounds (32) was the first to report that, in spite of a high prevalence of Raynaud's phenomenon, none of the forest workers questioned considered the disability great enough to give up his job. In the comprehensive report of Kylin \& Lidström (58), who investigated a group of 435 lumberjacks, Raynaud's phenomenon seemed to cause some or moderate disability in $45 \%$ of the afflicted lumberjacks, whereas in $55 \%$ the disease was not a handicap. According to personal reports in a followup study of 187 lumberjacks from Suomussalmi, Finland, in $1975(95,98), 42$ of the 45 lumberjacks still having attacks of Raynaud's phenomenon found the symptoms mild, and three experienced them as difficult or disabling. Only one of the lumberjacks rated his symptoms as severe enough to reduce wages. Corresponding data from Japan, Canada, and the United States are not yet available.

\section{Disability caused by paresthesias of the hands and arms}

Peripheral nervous symptoms can be severe. Klimková-Deutschová (55) reported that about $60 \%$ of her sample of industrial workers using vibrating tools suffered from severe numbing of the hands and arms. This symptom was present in 101 of 187 lumberjacks studied in Finland in $1975(95,98)$. Eighty of the lumberjacks found the symptoms to be minor, but in 21 the handicap was marked. In 9 of the 21 lumberjacks with marked nervous symptoms the extent of numbing was so severe that it caused a reduction in wages. This disability category, however, also includes cases with different nerve entrapment phenomena $(7,19)$. A disability caused by vibration neuropathy itself cannot be established on the basis of the data available so far.

\section{Disability caused by excessive muscle fatigue}

Information available on a decrease in muscular force is contradictory. Hellström \& Lange Andersen (38) did not find any observable changes in the muscular force of forest workers using chain saws when compared with that of nonusers. Subjectively this symptom was, however, frequently reported $(56,73,98,110)$. Thirtysix forest workers out of the 187 studied in Finland in $1975(95,98)$ felt a weakening of grip force. Twentynine of them felt it was no major handicap, but seven reported considerable disability. In four of the seven the extent of disability was so severe that earnings had been reduced. Thus excessive muscle fatigue may be a reason for disability.

\section{Objective tests of vibration syndrome}

Tests for vibration-induced white finger

A cold provocation test with different modifications has been used to assess vibration-induced vascular disturbances. It also seems to correlate positively with the number of affected digits $(5,83,89,97)$. In tests in which Raynaud's phenomenon is detected only by general visual inspection, a negative result does not exclude the possibility of this disorder. The proportion of positive tests among men with a history of VWF 
varies between 40 and $95 \%(5,58,86,88,97)$. Furthermore, the results of the cold provocation test can vary in repeated trials with the same individual. Among the forest workers of Suomussalmi, Finland, repetition of the field test increased the percentage of positive results from 45 to $67 \%(96,97)$. In the cases with a negative test result the extent of the disease was, in general, mild.

A cold provocation test combined with the measurement of systolic blood pressure in the finger in straingauge plethysmography has been proposed to be more accurate than bare visual inspection $(79,80,81,114)$, although the few studies where both techniques have been compared do not confirm this proposal (96). Several reports have indicated that systolic blood pressure is reduced in the finger during local cooling in about 60 to $86 \%$ of those affected with VWF $(10,84,112)$. Proper use of the technique is, however, required, ie, several local cooling temperatures ranging from 30 to $5^{\circ} \mathrm{C}$ should be used $(40,114)$ and the upper body should be cooled simultaneously $(3,10,80)$. The blood circulation in the digit should be arrested for $5 \mathrm{~min}$ during each cooling period. If the systolic blood pressure of the cooled digit stays significantly lower than that of the control digit, a positive VWF finding can be recorded $(10,79)$. However, some researchers point out that, for a positive sign of VWF, zero pressure should be reached (84). Each laboratory has, however, some modifications of the technique to enhance the number of positive results $(10,80,112)$. In this test, too, cases with low severity and only occasional bouts of VWF tend to remain undetected, as was recently seen in the Suomussalmi field study. In another prospective study, however, Olsen \& Nielsen (84) and Juul $\&$ Nielsen (54) indicated that, with this technique, they could predict about $70 \%$ of the subjects with VWF without knowing their history.

Recording the recovery of skin temperature from the fingers after cooling in water has been widely employed. The advantage of this test is that several fingers can be tested simultaneously and the equipment is relatively easy to use (117). Furthermore, the test can be conducted even under primitive conditions, eg, in the workplace (16). Several variations of the method exist. The temperature of cooling water varies between 4 and $10^{\circ} \mathrm{C}$, and the duration of the cooling between 1 and $10 \mathrm{~min}$. The length of the follow-up after the end of the cooling should last at least $15 \mathrm{~min}$. The finger temperature change during these intervals reflects changes in digital blood flow and thus indirectly measures the degree of vasospasm induced by cold. According to some experts the results of this method are not as reliable as those achieved with finger plethysmography (22).

Recently, it has been indicated that in victims with VWF flow reduction precedes pressure reduction during a cold provocation test (92). Thus, evaluating flow or, preferably, variables linked to peripheral resistance could lead to better diagnostic accuracy $(92,96)$. Es- timating peripheral resistance requires, however, arterial blood flow and venous pressure computation, in addition to measurements of systolic blood pressure in the finger, since the results cannot be directly linked to such a manifestation as zero systolic blood pressure in the finger. Furthermore simultaneously occurring powerful pressure and flow reduction may erroneously influence the peripheral resistance computation. This influence may be avoided if measurements during cold provocation tests are conducted at several cooling temperatures.

Laser Doppler flowmetry may assist blood flow measurements, but it requires external calibration and thus cannot replace strain-gauge plethysmography in quantitative evaluations. However, it is very useful in the evaluation of vasomotor oscillation (94) and the integrity of the vessel wall in the autonomic nervous system (62).

A thermographic technique does not increase the sensitivity of the cold provocation test. Furthermore, plethysmography $(23,86,88,95,119)$ of the digits without cold provocation, as well as angiography (46) of the hands and arms, has not been proved to be a suitable method for the diagnosis of VWF.

\section{Tests for peripheral nerves and receptors}

Measurements of the sensory and motor conduction velocity of peripheral nerves have been used in estimations of nerve injury $(2,8,19,63,82,104)$. The disadvantage of this method is its nonspecificity for vibration-induced pathology since neuropathies are rather frequently found among workers who are not exposed to vibration $(21,52,82)$. Multiple entrapments affecting the nerve trunks at different sites may cause symptoms similar to those of vibration neuropathy $(7$, $66)$. Because of the nonspecifity and wide spread of normative values, some researchers $(2,19,63)$ are very cautious in interpreting the results of nerve conduction velocity measurements. Furthermore, a high prevalence of polyneuropathy has been reported for a group referred to neurophysiological examination because of suspected vibration syndrome (53). This finding may indicate selection with respect to vibration syndrome for persons with a tendency towards general neuropathic diathesis.

The etiology of nerve injury in the vibration syndrome and in entrapment syndromes may be very similar. In fact, by exposing animals to acute vibration, Lundborg (64) showed that the perineurium will leak fluid, and this occurrence can lead to the development of perineural edema. Since the perineurium prevents the enlargement of the nerve by its stiffness, there will be increased pressure inside the nerve that leads to a compartment syndrome. Since the myelin sheath is very sensitive to pressure, a reduction in the motor and sensory conduction velocities will be observed. Thus, the neurophysiological findings of the vibration syn- 
drome may be identical to carpal tunnel syndrome and other entrapment neuropathies.

Measurements of nerve conduction velocities of myelinated fibers do not definitely reveal whether vibration neuropathy also causes axonal degeneration, eg, in postganglionic sympathetic fibers which lack a myelin sheath. Up to now no specific tests have been available for these fibers, even though they control digital circulation. Recording single fiber activity of efferent sympathetic nerves, as done by Hagbarth et al (35), may show whether the nonmyelinated fibers are also affected in vibration neuropathy. Furthermore the extent to which axonal degeneration occurs in vibration neuropathy still remains to be elucidated. No test at present can confirm or exclude prominent axonal degeneration in the vibration syndrome.

\section{Vibrotactile sensation}

Several of the receptor systems of the skin perceive vibration. On the basis of the properties of adaptation to constant pressure, two receptor populations can be discerned, the slowly adapting (SA) and fast adapting (FA) types (51). A further distinction between the receptor population can be achieved in studies of the receptive fields. Receptors responding to contact with objects with small sharp edges are composed of SA I and FA I types, which have been anatomically linked to the Merkel cell neurite complex and Meissner's corpuscles (51), respectively. Receptors responding to contact with objects with large, obscure borders are composed of SA II and FA II types, which have been linked anatomically to Ruffini endings and pacinian corpuscles.

The neural responses to vibration derive from stimulation of the receptor populations, the populations stimulated depending on the stimulus frequency. At psychophysical thresholds in the low-frequency range $(0.1$ to $60 \mathrm{~Hz})$ mainly SA receptors perceive vibration, whereas at higher frequencies (above $60 \mathrm{~Hz}$ ) mainly FA receptors perceive vibration (76).

Of the two types of FA receptors, the pacinian corpuscles, which correspond to the FA II receptors, are highly sensitive and respond even to faint displacement of the skin in distant areas of the body (50). Moreover, even if FA I and FA II receptors are equally potent in eliciting neural responses, the psychophysical correlations relate to the FA II type, since even one impulse from an FA II receptor can elicit a sensation, whereas a summation of several impulses is required of FA I receptors to produce a corresponding sensation (49).

In SA receptor populations, the SA I type seems to be more potent than the SA II type since SA I receptors show a prominent potentiation with respect to the shape of objects and vibrotactile perception (48). This quality makes SA I receptors an effective receptor system in tasks requiring manipulative dexterity. Clinical tests, eg, two-point discrimination, may be used to evaluate the function of SA I receptors. In support of this idea a pathological value for two-point discrimination was found mainly among those subjects who had a pathological value in their vibrogram also at the lowest test frequencies (48). The most sensitive frequency range is $250-350 \mathrm{~Hz}$, where, in normal subjects, pacinian corpuscles can detect displacement of the skin at an amplitude of $0.1 \mu \mathrm{m}$ (77). Thus, vibrograms at different frequencies may evaluate separate receptor systems, and in certain instances the vulnerability of these systems in lesions can be separately determined. A relatively well preserved two-point discrimination corresponds to the relatively mild sensory loss seen in vibrograms at low frequencies (65).

The reduced vibrotactile sensitivity related to the carpal tunnel syndrome at higher vibration frequencies may not depend on a degeneration of the FA II receptors. The high frequency sensibility loss in the carpal tunnel syndrome may be explained by dysfunction of the afferent nerves due to ischemia. Thus, in carpal tunnel syndrome due to a local compression of the nerve trunk, the conduction of the myelinated sensory fibers is retarded, and, when the process continues, a loss of fibers occurs. The repolarization of the nerve is prolonged and finally vibrotactile sensitivity is affected at lower frequencies (82). The type of sensory loss seen in the vibrogram can, in this way, mirror the severity of nerve ischemia in carpal tunnel syndrome, as was observed in one study (65).

A psychophysical vibration detection test is widely used to determine vibrotactile sensitivity $(1,75,95,107$, 109). However, various investigators $(1,17,95,107$, 109) have faced difficulties in interpreting the results of the test. There exists a wide overlap in the threshold values of disabled and symptom-free subjects. For example normal vibrotactile thresholds have been found among forest workers with and without VWF (1). The neurological findings in a clinical evaluation were not associated with vibrotactile threshold elevation (28) in forest workers. However, among a group of grinders (who had severe vibration syndrome) pathologically elevated vibrotactile detection thresholds were observed (107). Vibration detection tests should probably be used to supplement other diagnostic techniques or to discriminate between patients on a group basis.

As for psychophysical vibration detection thresholds, the tactile discrimination tests and electrically measured sensory threshold tests $(85,109)$ are currently of limited value. Knowledge in this field is, however, increasing and presumably a more useful test will eventually be developed $(17,19,87)$.

\section{Tests for the bones and joints}

Some studies have shown that occupational vibration may lead to bone cysts or vacuoles that are detectable in radiographs $(41,57,59,113)$. Other studies have not found any differences in bone degeneration be- 
tween vibration exposed and unexposed groups (34, $38,47)$. Furthermore many workers using vibrating tools suffer from painful and stiff joints without any radiographic changes being evident. Thus radiographs are of dubious value in the diagnosis of vibration syndrome in individual cases, unless the character of the vibration is very impulsive and the frequency low.

\section{Conclusions}

At present it seems likely that the different components of the vibration syndrome, eg, VWF, numbing of the hands and arms, muscular fatigue, and bone degeneration, may arise independently, and therefore they should be evaluated separately. The lack of simple objective tests for evaluating the syndrome makes it difficult to, eg, confirm the history of its different components objectively and estimate the extent of the disability it causes. Evidence indicating changes initiated in the autonomic functions of the body by local vibration is not conclusive.

\section{References}

1. Aatola S, Starck J, Pyykkö I, Färkkilä M, Korhonen O. Vibration detection threshold of lumberjacks. In: International symposium on the protection of workers against vibration, Nis Yugoslavia Sept 21-24, 1982. Niš 1983, pp 347-351.

2. Abnizzese M, Loeb C, Ratto S, Sacco G. A comparative electrophysiological and histological study of sensory conduction velocity and Meissner's corpuscles of the median nerve in pneumatic tool workers. Eur Neurol 16 (1977) 106-114.

3. Abrahams DI. Circulation in the extremities. Academic Press Inc, New York, NY 1967, p 557.

4. Agate JN. An outbreak of cases of Raynaud's phenomenon of occupational origin. Br J Ind Med 6 (1949) 144-163.

5. Agate JN, Druett HA. A study of portable vibrating tools in relation to the clinical effect which they produce. Br J Ind Med 4 (1947) 141-163.

6. Agate JN, Druett HA, Tombleson JBL. Raynaud's phenomenon in grinders of small metal castings. $\mathrm{Br} \mathrm{J}$ Ind Med 3 (1946) 167-174.

7. Ahlborg G, Voog L. Vibration exposure and distal compression of the median nerve ("carpal tunnel syndrome"). Läkartidningen 79 (1982) 4905-4908.

8. Alaranta H, Seppäläinen A-M. Neuropathy and the automatic analysis of electromyographic signals from vibration exposed workers. Scand J Work Environ Health 3 (1977) 128-134.

9. Andreeva-Galanina ET, Karpova NI. On degeneration and regeneration of peripheral nerves under the effect of experimental vibration [in Russian]. Gig Tr Prof Zabol 13 (1969): 2, 4-7. (English abstract).

10. Arneklo-Nobin B. The white cold hand. University of Lund, Lund, Sweden 1983. (Doctoral thesis).

11. Asanova TP. Vibration disease among workers using portable power tools in Finnish shipyards. In: Korhonen $\mathrm{O}$, ed. Vibration and work: Proceedings of the Finnish-Soviet-Scandinavian vibration symposium, Helsinki, March 10-13, 1975. Institute of Occupational Health, Helsinki 1976, pp 52-62.

12. Ashe WF, Cook WT, Old JW. Raynaud's phenomenon of occupational origin. Arch Environ Health 5 (1962) $333-343$.
13. Banister PA, Smith FW. Vibration induced white fingers and manipulative dexterity. $\mathrm{Br} \mathrm{J}$ Ind Med 29 (1972) 264-267.

14. Bannister R, Sever P, Gross M. Cardiovascular reflexes and biochemical responses in progressive autonomic failure. Brain 100 (1977) 327-344.

15. Blair HM, Headington JT, Lynch PJ. Occupational trauma, Raynaud phenomenon, and sclerodactylia. Arch Environ Health 28 (1974) 80-81.

16. Bovenzi M, Petronio L, Di Mario F. Epidemiological survey of shipyard workers exposed to hand-arm vibration. Int Arch Occup Environ Health 46 (1980) $251-266$.

17. Brammer AJ, Taylor W, Piercy JE. Assessing the severity of the neurological component of the handarm vibration syndrome. Scand J Work Environ Health 12 (1986) 428-431.

18. Brubaker RL, Bates DV, Eng PR. The prevalence of white finger among fellers in coastal British Columbia. Faculty of Medicine, Department of Health Care and Epidemiology, University of British Columbia, Vancouver 1982 .

19. Chatterjee DS, Barrwick DD, Pertrie A. Exploratory electromyographing in the study of vibration-induced white finger in rock drillers. $\mathrm{Br} \mathrm{J}$ Ind Med 39 (1982) 89-97.

20. Dart EE. Effect of high speed vibrating tools on operators engaged in the airplane industry. $\mathrm{J}$ Occup Med 1 (1946) 515-550.

21. Fagius J. Chromic cryptogenic polyneuropathy. Acta Neurol Scand 67 (1983) 173-180.

22. Ekenvall L, Lindblad L-E. Digital blood pressure after local cooling as a diagnostic tool in traumatic vasospastic disease. Br J Ind Med 39 (1982) 388-391.

23. Futatsuka M, Pyykkö I, Färkkilä M, Korhonen $O$, Starck J. Blood pressure, flow and peripheral resistance of digital arteries in vibration syndrome. $\mathrm{Br} \mathrm{J}$ Ind Med 40 (1983) 343-441.

24. Futatsuka M, Takamatsu M, Sakurai T, Maeda K, Esaki $\mathrm{H}$, Hirosava I, Wakaba $\mathrm{K}$. Vibration hazards in forestry workers of chain saw operation in a determined area in Japan. J Sci Labour 56 (1980) 27-48.

25. Färkkilä M. Grip force in vibration disease. Scand J Work Environ Health 4 (1978) 159-166.

26. Färkkilä M, Pyykkö I, Korhonen O, Starck J. Hand grip forces during chain saw operation and vibration induced white finger in lumberjacks. $\mathrm{Br} \mathrm{J}$ Ind Med 36 (1979) 336-341.

27. Färkkilä M, Pyykkö I, Korhonen O, Starck J. Vibration-induced decrease in the muscle force in lumberjacks. Eur J Appl Physiol 43 (1980) 1-9.

28. Färkkilä M, Starck J, Aatola S, Pyykkö I, Korhonen O. Vibration-induced neuropathy among forest workers. Acta Neurol Scand 71 (1985) 221-225.

29. Färkkilä M, Starck J, Hyvärinen J, Kurppa K. Vasospastic symptoms caused by asymmetrical vibration exposure of the upper extremities to a pneumatic hammer. Scand J Work Environ Health 4 (1978) 330-335.

30. Gemne G. "Vibration disease" as a central nervous disorder - Development, symptomatology, and pathophysiology of Soviet and Japanese classifications. J Low Freq Noise Vib 1 (1983): special issue, 19-35.

31. Gemne G. Autonomic integration of external and internal stimuli, and the Soviet concept of "diencephalic syndrome." J Low Freq Noise Vib 1 (1983): special issue, 63-68.

32. Grounds MD. Raynaud's phenomenon in users of chain saws. Med J Aust 22 (1964) 270-272.

33. Gurdjian ES, Walker LW. Traumatic vasospastic disease of the hand (white fingers). J Am Med Assoc 129 (1945) 668-672.

34. Härkönen $H$, Riihimäki $H$, Tola $S$, Mattsson T, Pekkarinen M, Zitting A, Husman K. Symptoms of vi- 
bration syndrome and radiographic findings in the wrists of lumberjacks. Br J Ind Med 41 (1984) $133-136$.

35. Hagbarth K-E, Hallin RG, Hongel A, Torebjörk HE, Wallin BG. General characteristics of sympathetic activity in human skin nerves. Acta Physiol Scand 84 (1972) 167-176.

36. Hamilton A. A vasomotor disturbance in the fingers of stonecutters. Arch Gewerbepath Gewerbehyg 1 (1930) 348-358.

37. Hamilton A. Bulletin of US Department of Labor, no 236, Bureau of Labor Statistics (1918). Cited by Agate JN, Druett HA. A study of portable vibrating tools in relation to the clinical effect which they produce. $\mathrm{Br}$ $\mathrm{J}$ Ind Med 4 (1947) 141-163.

38. Hellstrom B, Lange Andersen $\mathrm{K}$. Vibration injuries in Norwegian forest workers. Br J Ind Med 29 (1972) $255-263$.

39. Hines S, Houston M, Robertson D. The clinical spectrum of autonomic dysfunction. Am J Med 70 (1981) $1091-1096$.

40. Hirai M, Nielsen SL, Lassen NA. Blood pressure mea surements of all five fingers by strain gauge plethysmography. Scand J Clin Lab Invest 36 (1976) 627-632.

41. Horváth F, Kákosy T. Asetische Nekrosen an Handwurzelknochen von Motorsägearbeitern. Z Orthop 111 (1973) 906-913.

42. Hughes RC, Cartlidge NEF, Millac P. Primary neuro genic orthostatic hypotension. J Neurol Neurosurg Psychiatry 33 (1970) 363-371.

43. Hyvärinen J, Pyykkö I, Sundberg S. Vibration in frequencies and amplitudes in the aetiology of traumatic vasospastic disease. Lancet 1 (1973) 791-794

44. Iki M, Kurumatani N, Hirata K, Moriyama T. An association between Raynaud's phenomenon and hearing loss in forestry workers. Am Ind Hyg Assoc J 46 (1985) $509-513$.

45. Iki M, Kurumatani N, Moriyama T. Vibration-induced white fingers and hearing loss. Lancet 1 (1983) 282283.

46. James PB, Galloway RM. Arteriography of the hand in men exposed to vibration. In: Taylor W, Pelmear PL, ed. Vibration white finger in industry. Academic Press, London-New York-San Francisco 1975, pp $31-41$.

47. James PB, Yates JR, Pearson JG. An investigation of the prevalence of bone cysts in hands exposed to vibration. In: Taylor W, Pelmear PL, ed. Vibration white finger in industry. Academic Press, London-New York-San Francisco 1975, pp 43-51.

48. Johansson RS, Landström U, Lundström R. Sensitivity to edges of mechanoreceptive afferent units innervating the glabrous skin of the human hand. Brain Res 244 (1982) $27-32$.

49. Johansson RS, Wallbo ÅB. Detection of tactile stimuli: Thresholds of afferent units related to psychophysical thresholds in the human hand. J Physiol (London) 297 (1979) 405-422.

50. Johansson RS, Wallbo ÅB. Spatial properties of the population of mechanoreceptive units in the glabrous skin of the human hand. Brain Res 184 (1980) 353366.

51. Johansson RS, Wallbo ÄB. Tactile sensory coding in the glabrous skin of the human hand. Trends Neurosci 6 (1983) 27-32.

52. Juntunen J, Haltia M. Polyneuropathies in occupational neurology: Pathogenetic and clinical aspects. Acta Neurol Scand 66 (1982): suppl 92, 59-73.

53. Juntunen J, Matikainen E, Seppäläinen A-M, Laine A. Peripheral neuropathy and vibration syndrome. Int Arch Occup Environ Health 52 (1983) 17-24.

54. Juul C, Nielsen SL. Locally induced digital vasospasm detected by delayed rewarming in Raynaud's phenom- enon of occupational origin. Br J Ind Med 38 (1981) $87-90$.

55. Klimková-Deutschová E. Neurologische Aspekte der Vibrationskranheit. Arch Gewerbepath Gewerbehyg 22 (1966) 297-305.

56. Korhonen $O$, Nummi J, Nurminen M, Nygård K, Soininen $\mathbf{H}$, Wiikeri M. Metsätyöntekijä: Osa 2. Terveys verrattuna ammatissa toimivan väestön terveyteen. Institute of Occupational Health, Helsinki 1977. (Työterveyslaitoksen tutkimuksia 126).

57. Kumlin T, Wiikeri M, Sumari P. Radiological changes in carpal and metacarpal bones and phalanges caused by chain saw vibration. Br J Ind Med 30 (1973) 71-73.

58. Kylin B, Lidström I-M. Hälso- och miljöundersökning bland skogsarbetare. AI-rapport 5 (1968) 44-52.

59. Laitinen J, Puranen J, Vuorinen P. Vibration syndrome in lumbermen (working with chain saws). J Occup Med 8 (1974) 552-556.

60. Lewis T. Vascular disorders of the limbs. Second edition. MacMillan, London 1949.

61. Lidström I-M. Vibration injury among rock drillers, chiselers and grinders: Some views on the relationship between the quantity of energy absorbed and the risk of injury. In: Korhonen O, ed. Vibration and work: Proceedings of the Finnish-Soviet-Scandinavian vibration symposium, Helsinki March 10-13, 1975. Institute of Occupational Health, Helsinki 1976, pp 81-88.

62. Low PA, Neuman C, Dyck PJ, Fealey RD, Tuck RR. Evaluation of skin vasomotor reflexes by using laser Doppler velocimetry. Mayo Clin Proc 58 (1983) 583592.

63. Lucas E. Peripheral nervous system and hand arm vibration. In: Brammer AJ, Taylor W, ed. Vibration effects on the hand arm in industry. John Wiley and Sons, New York, NY 1982, pp 39—43.

64. Lundborg G. Experimentella modeller för studium av vibrationsinducerade nerv och kärlskador. In: Arbetarskyddsfonden. Handöverförda vibrationer. Stockholm 1983, pp 137-140.

65. Lundborg G, Lie-Stenström OT, Sollerman C, Pyykkö I. Digital vibrogram - A new diagnostic tool for sensory test in compression neuropathy. J Hand Surg (in press).

66. Matikainen E, Juntunen J. Neuropathies due to physical factors and entrapment in occupational neurology. Acta Neurol Scand 66 (1982): suppl 92, 211-218.

67. Matoba T, Chiba M, Inutsuba S. Autonomic nervous disorders in subjects exposed to hand arm vibration: A review of clinical investigations in Japan. J Low Freq Noise Vib 1 (1983): special issue, $74-83$.

68. Matoba T, Chiba M, Toshima T. Cardiovascular features of vibration syndrome: An adaptive response. In: Brammer AJ, Taylor W, ed. Vibration effects on the hand and arm in industry. John Wiley and Sons, New York, NY 1982, pp 25-30.

69. Matoba $\mathrm{T}$, Itaya $\mathrm{M}$, Toyomasu $\mathrm{K}$, Tsuiki $\mathrm{T}$, Toshima $\mathrm{H}$, Kuwahare $\mathbf{H}$. Increased left ventricular function as an adaptive response in vibration disease. Am J Cardiol 51 (1983) 1223-1226.

70. Matoba I', Kusumoto H, Kuwahara H, Ivanaga K, Oshima M, Takamatsu M, Esaki K. Pathophysiology of vibration disease. Jpn J Ind Health 17 (1975) 11-18.

71. Matoba T, Kusumoto H, Takamatsu M. A new criterion of the severity of the vibration disease. Jpn J Ind Health 17 (1975) 211-214.

72. Matoba $\mathrm{T}$, Mizobuchi $\mathrm{H}$, Ito $\mathrm{T}$, Chita $\mathrm{M}$, Toshima $\mathrm{H}$ Further observations of the digital plethysmography in response to auditory stimuli and its clinical applications. Angiology 32 (1981) 62-72.

73. Matsumoto K, Itoh N, Kasamatsu T, Iwata H. A study on subjective symptoms based on total operating time of chain saw. Jpn J Ind Health 191 (1977) 22-28.

74. Miura T. On the vibration syndrome in Japan due to 
hand held vibrating tools. J Sci Labour 51 (1975) $771-787$.

75. Miura T, Kumura K, Toimiaga Y, Kimotsuki KJ. On Raynaud's phenomenon of occupational origin due to vibrating tools [in Japanese]. J Sci Labour 42 (1965) 725-747. (English abstract).

76. Mountcastle VB, Talbot WH, Darian-Smith I, Kornhuber HH. Neural basis of the sense of flutter-vibration. Science 155 (1967) 597-600.

77. Mountcastle VB, Talbot WH, Sakata H, Hyvärinen J. Cortical neuronal mechanisms in flutter-vibration studied in unanesthetized monkeys: Neuronal periodicity and frequency discrimination. J Neurophysiol 32 (1967) 452 - 484.

78. Nalca IF. Vascular disorders and their pathogenesis in connection with vibration disease [in Russian]. Sovetsk Med 34 (1971) 11-14. (English abstract).

79. Nielsen SL. Raynaud's phenomenon and finger systolic pressure during cooling. Scand J Clin Lab Invest 38 (1978) $765-770$.

80. Nielsen SL, Lassen NA. Measurement of digital blood pressure after local cooling. J Appl Physiol 43 (1977) 907-910.

81. Nielssen HV. Arterial pressure - Blood flow relations during limb elevation in man. Acta Physiol Scand 118 (1983) 405-413.

82. Oh SJ. Clinical electromyography: Nerve conduction studies. University Park Press, Baltimore, MD 1984.

83. Okada A, Yamashita T, Nagano C, Ikeda T, Yachi A, Shibata S. Studies on the diagnosis and pathogenesis of Raynaud's phenomenon of occupational origin. $\mathrm{Br}$ $J$ Ind Med 28 (1971) 353-357.

84. Olsen N, Nielsen SL. Diagnosis of Raynaud's phenomenon in quarrymen's traumatic vasospastic disease. Scand J Work Environ Health 5 (1979) 249-256.

85. Pelmear PL, Taylor W, Pearson JCG. Clinical objective tests for vibration white finger. In: Taylor W, Pelmear PL, ed. Vibration white finger in industry. Academic Press, London-New York-San Francisco 1975, pp 53-81.

86. Pelnar PV, Gibbs GW, Pathak BP. A pilot investigation of the vibration syndrome in forestry workers of eastern Canada. In: Brammer AJ, Taylor W, ed. Vibration effects on the hands and arms in industry. John Wiley and Sons, New York, NY 1982, pp 173-187.

87. Piercy JE, Brammer AJ, Taylor W. Physiological noise and its influence on vibrotactile perception thresholds. Scand J Work Environ Health 12 (1986) 417-419.

88. Pyykkö I. A physiological study of the vasoconstrictor reflex in traumatic vasospastic disease. Work Environ Health 11 (1974) 170-186.

89. Pyykkö I. The prevalence and symptoms of traumatic vasospastic disease among lumberjacks in Finland. Work Environ Health 11 (1974) 118-131.

90. Pyykkö I. Katsaus tärinän teveydellisiin haittoihin. In: Institute of Occupational Health. XXII työterveyspäivät. Helsinki 1975, pp 35-48.

91. Pyykkö I. Vibration syndrome: A review. In: Korhonen $\mathrm{O}$, ed. Vibration and work: Proceedings of the Finnish-Soviet-Scandinavian vibration symposium, Helsinki, March 10-13, 1975. Institute of Occupational Health, Helsinki 1976, pp 1-24.

92. Pyykkö I, Kolari P, Färkkilä M, Starck J, Korhonen $O$, Jäntti V. Finger peripheral resistance during cold provocation in vasospastic disease. Scand J Work Environ Health 12 (1986) 395-399.

93. Pyykkö I, Gemne G, Kolari P, Starck J, Ilmarinen R, Aalto $\mathrm{H}$. Vasomotor oscillation in vibration-induced white finger. Scand J Work Environ Health 12 (1986) 389-394.

94. Pyykkö I, Hyvärinen J. Vibration induced changes of sympathetic vasomotor tone. Acta Chir Scand Suppl 465 (1976) $23-26$.
95. Pyykkö I, Korhonen O, Färkkilä M, Starck J, Aatola A. A longitudinal study of vibration syndrome among Finnish forest workers. In: Brammer AJ, Taylor W, ed. Vibration effect on the hand and arm in industry. John Wiley and Sons, New York, NY 1982, pp 157167.

96. Pyykkö I, Korhonen O, Färkkilä M, Starck J, Aatola $S$. Cold provocation tests in the evaluation of vibrationinduced white finger. Scand $\mathrm{J}$ Work Environ Health 12 (1986) 254-258.

97. Pyykkö I, Korhonen O, Starck J, Färkkilä M. Cold provocation test and TVD index in determining severity of vibration-induced white finger. In: Proceeding of the international symposium on the protection of workers against vibration, Nis Yugoslavia, Sept 21-24 1982. Niš 1983, pp 147-159.

98. Pyykkö I, Sairanen E, Korhonen O, Färkkilä M, Hyvärinen J. A decrease in the prevalence and severity of vibration-induced white fingers among lumberjacks in Finland. Scand J Work Environ Health 4 (1978) 246254.

99. Pyykkö I, Starck J, Färkkilä M, Aatola S, Korhonen $O$. Relation between noise-induced permanent threshold shift and vibration-induced white finger. Am J Otol (in press)

100. Pyykkö I, Starck J, Färkkilä M, Hoikkala M, Korhonen $O$, Nurminen $M$. Hand-arm vibration in the aetiology of hearing loss in lumberjacks. Br J Ind Med 38 (1981) $281-289$.

101. Raynaud M. De l'asphyxie et de la gangréne symétrique des estrémités. Rignou, Paris. (Doctoral thesis). Cited by Birnstingl M. The Raynaud syndrome. Postgrad Med J 47 (1971) 297-310.

102. Riddle HFV, Taylor W. Vibration-induced white finger among chain sawyers nine years after the introduction of anti-vibration measures. In: Brammer AJ, Taylor $W$, ed. Vibration effects on the hand and arm in industry. John Wiley and Sons, New York, NY 1982, pp 169-172.

103. Schatz IS, Podalsky S, Frame B. Idiopathic orthostatic hypotension: Diagnosis and treatment. J Am Med Assoc 186 (1963) 537-540.

104. Seppäläinen A-M. Peripheral neuropathy in forest workers: A field study. Work Environ Health 9 (1972) $106-111$.

105. Steward AM, Goda DF. Vibration syndrome. Br J Ind Med 27 (1970) 19-27.

106. St Clair Renard KG. Kärlkramp vid borringsarbetare. Medd Svenska Grufören 7 (1963) $1-55$.

107. Starck J, Färkkilä M, Aatola S, Pyykkö I, Korhonen $\mathrm{O}$. Vibration syndrome and vibration in pedestal grinding. Br J Ind Med 47 (1983) 426-433.

108. Taylor $W$. The vibration syndrome: Introduction. In: Taylor W, ed. The vibration syndrome. Academic Press Inc, London-New York 1974, pp 1-12.

109. Taylor W, Pelmear PL, Pearson J. Raynaud's phenomenon in forestry chain saw operators. In: Taylor W, ed. The vibration syndrome. Academic Press Inc, London-New York 1974, pp 121-139.

110. Teleky L. Pneumatic tools. Occup Health 1 (1938) $1-12$.

111. Thomas JE, Schirger A. Neurologic manifestations in idiopathic orthostatic hypotension. Arch Neurol 8 (1963) 204-208.

112. Thulesius $\mathrm{O}$, Brubaker $\mathrm{A}$, Berlin $\mathrm{E}$. Response of digital blood pressure to cold provocation in cases with Raynaud's phenomenon. Angiology 32 (1981) 113118.

113. Vainio $\mathrm{K}$. Om vibrationssyndrom, särskilt hos maskinborrare. Nord Hyg Tidskr 31 (1950) 249-265.

114. Voss $P$, Olsen N, Nielsen SL. Vibrationsskader fra håndvärketöjer. Hovedrapport. Lydteknik, Teknologisk Insitut, Tåstrup, Danmark 1979. 
115. Walton KW. The pathology of Raynaud's phenomenon of occupational origin. In: Taylor W, ed. The vibration syndrome. Academic Press Inc, London-New York 1974, pp 109-119.

116. Watanabe M. White hand disease (local vibration disturbances). Hoppo Ringyo 209 (1966) 213-219.

117. Welsh CL. Digital rewarming time in the assessment of vibration induced white finger. Scand J Work Environ Health 12 (1986) $249-250$.

118. Williams RL, Karacan I. Sleep disorders diagnosis and treatment. Raven Press, New York, NY 1978.

119. Zweifler AJ. Detection of occlusive arterial disease in the hand and its relevance to occupational hand disease. In: Wasserman DE, Taylor W, ed. Proceedings of the international occupational hand-arm vibration conference. National Institute for Occupational Safety and Health, Cincinnati, OH 1977, pp 12-20.

Received for publication: 12 March 1986 